\title{
Lymphocyte Cyclic Nucleotides and Cellular Immunity in Viral Hepatitis
}

\author{
Yoshio TAOKA ${ }^{1}$ and Takayoshi ENDO ${ }^{2}$ \\ ${ }^{1}$ Department of Internal Medicine and Clinical Toxicology, School of Medicine, University \\ of Occupational and Environmental Health, Japan. Kitakyushu 807, Japan \\ ${ }^{2}$ Nishisawada Clinic. Numazu 410, Japan
}

\begin{abstract}
It has been known that contents of intra-cellular cyclic nucleotides, cyclic $3^{\prime}, 5^{\prime}$-adenosine monophosphate (cyclic AMP) and cyclic $3^{\prime}, 5^{\prime}$-guanosine monophosphate (cyclic GMP), in T-lymphocytes are closely related with cell-mediated immunity of the host since the first investigations by Lichtenstein \& Margolis (1968). However, this problem has never been studied in human viral hepatitis. Therefore, we began the clinical and experimental studies on this problem. It is illustrated in this study that the intracellular cyclic-AMP content of $\mathrm{T}$-lymphocyte in peripheral blood was enhanced by an addition of phytohemagglutinin (PHA) to lymphocyte culture medium. The increase-rate of lymphocytic cyclic-GMP content caused by the addition of similar mitogen was reduced in patients of chronic active hepatitis when compared with normal control. The relationship between the contents of intracellular (lymphocytes) cyclic AMP and serum levels of $\alpha_{2}$-macroglobulin which is thought to be one component of serum inhibitors against the non-specific cellmediated immunity in our previous data was investigated in this study, and these markers showed the parallel variation with each other in the patients of viral hepatitis. On the other hand, the high cyclic AMP content and low cyclic GMP increase-rate by an addition of mitogen to peripheral T-lymphocyte culture medium (as well as high serum $\alpha_{2}$ macroglobulin levels) were seen in patients with chronic active hepatitis which meant a suppressed cellular immunity. In conclusion, a determination of cyclic nucleotides in T-lymphocytes is very useful to understand the involvement of them in cell-mediated immunity which is closely associated with chronicity of viral hepatitis.
\end{abstract}

Key words: cyclic nucleotides, cellular immunity, viral hepatitis.

(Received 15 August 1981)

\section{Introduction}

In our previous data (Taoka \& Endo, 1978; 1979a, b, c; 1980a, b, c; Taoka, 1980), we have illustrated that the T-cell population and function were mostly decreased in murine and human chronic active hepatitis and progressive liver cirrhosis, and the serum inhibitors against cell-mediated immunity including $\alpha_{2}$-macroglobulin were generally increased. Also, we observed that the suppressor- $T$ cell function was decreased in the cases of chronic active hepatitis and progressive liver cirrhosis, and ${ }^{51} \mathrm{Cr}$-labeled T-lymphocytes were transferred to the liver and a high uptake of radio-activities on the liver surface 
was observed in chronic active hepatitis.

On the other hand, Hirschhorn et al. (1970) suggested that cyclic 3', 5'-adenosine monophosphate (cyclic AMP) mediated the lymphocyte transformation by phytohemagglutinin (PA.H) and subsequently, Smith et al. (1971a, b) described that aminophylline, isoproterenol and prostaglandin, all of which elevate lymphocyte cyclic AMP levels, inhibited incorporation of ${ }^{3} \mathrm{H}$-labeled nucleotides and amino acid into the DNA, RNA and protein of PHA-stimulated lymphocytes. Henney et al. (1972) illustrated that the treatment of lymphocytes with adenyl cyclase stimulating agents including histamine, isoproterenol and prostaglandins $\mathrm{E}_{1}$ and $\mathrm{E}_{2}$ caused increases in cyclic AMP levels and inhibited cytolytic activity.

Hadden et al. (1972) reported that optimal mitogenic concentrations of PHA and concanavalin A (Con-A) produced marked increases in the concentration of lymphocyte cyclic $3^{\prime}, 5^{\prime}$-guanosine monophosphate (cyclic GMP) within the first $20 \mathrm{~min}$ of exposure to the mitogens. Also, they asserted that a temporally discrete rise in lymphocyte cyclic GMP concentration is viewed as an active signal to induce proliferation, while the elevation of cyclic AMP concentration in these cells is viewed as a regulatory influence that limits or inhibits mitogenic action.

However, no study has been done on the role of lymphocyte cyclic nucleotides in murine or human viral hepatitis associated with cell-mediated immunity. So, we wanted to confirm these results by basic experiments and clinical studies.

\section{Materials and Methods}

\section{Materials}

The patients with viral hepatitis who were admitted into our University Hospital and Tokyo Rosai Hospital were tested in this study, and their diagnoses were confirmed by a laparoscopy and liver biopsy.

For the in vitro experiment, highly purified materials of $\alpha_{1}$-acid glycoprotein $\left(\alpha_{1}-\mathrm{AG}\right)$ and $\alpha_{2}$-macroglobulin $\left(\alpha_{2}\right.$-M) were provided from Behringwerke AG, Marburg in W. Germany through the courtesy of Prof. Schwick.

\section{Methods}

Lymphocyte materials were separated from peripheral blood taken from the patients with viral hepatitis by the Ficoll-Angioconray method.

An adequate amount of phytohemagglutinin (PHA) for making transformation was added to the samples which contained approximately $1 \times 10^{6}$ lymphocytes, and then the equal volume of $12 \%$ Tricarboxylic acid (TCA) was also added for ceasing of reaction.

The samples were provided for the determination at 5, 10, 15 and $20 \mathrm{~min}$ before and after the adding of PHA, and were treated with an ultrasonicator for $5 \mathrm{~min}$ for the destruction of lymphocyte cell membrane.

Cyclic nucleotides in lymphocyte are contained in supernatant after a centrifugation. 
After the centrifugation of samples, an adequate volume of ether was added to the supernatant. After shaking, TCA was transferred into the ether portion whereas the cyclic nucleotides remain in the residual watery portion (precipitate are discarded). This procedure was repeated several times.

Subsequently, the whole of the watery fraction was dried in room temperature for the determination of cyclic nucleotides.

Cyclic AMP was determined by Steiner's method (Steiner et al., 1969) using anticyclic AMP serum produced by the Schwarzmann Company.

Cyclic GMP was assayed by Gilman-Murad's method (Gilman, 1970; Murad \& Gilman, 1971; Murad et al., 1971) using cyclic GMP binding protein produced by the Diagnostic Products Company.

\section{Results}

\section{Clinical problem}

(1) $\mathrm{T}$ cell population and function

Human lymphocytes of normal adults were added to the sera of hepatitis patients who had (or did not have) HBsAg and then were incubated or cultured in a $\mathrm{CO}_{2}$ incubator and were investigated for the population of rosette forming cells (RFC, T-lymphocytes) and blastogenesis by PHA (Table 1).

As shown in Table 1, the T-cell population is markedly lower in chronic active hepatitis $(26 \pm 11 \%)$ as compared with normal controls $(47 \pm 10 \%)$ and chronic persistent hepatitis $(48 \pm 12 \%)$.

Table 1. Immunological aspect of chronic virus hepatitis Functions of T-lymphocytes

\begin{tabular}{lcc} 
& Chronic active hepatitis & Chronic persistent hepatitis \\
\hline T cell population & $26 \pm 11 \%$ & $49 \pm 12 \%$ \\
Blastogenesis by PHA & $49 \pm 9 \%$ & $53 \pm 13 \%$ \\
\hline
\end{tabular}

Cyclic nucleotide contents and increase-rate of lymphocytes ( $\mathrm{p}$ mole $/ 1 \times 10^{7}$ of lymphocytes)

\begin{tabular}{|c|c|c|c|}
\hline & cyclic AMP & cyclic GMP & $\Delta \mathrm{c}-\mathrm{GMP} / 15 \mathrm{~min}$ \\
\hline Normal controls & $\begin{array}{l}6 \pm 3.9 \\
(\mathrm{n}=4)\end{array}$ & $\begin{array}{c}2.2 \pm 0.5 \\
(\mathrm{n}=2)\end{array}$ & $\begin{array}{l}40 \pm 3 \% \\
(n=2)\end{array}$ \\
\hline HBsAg asymptomatic carriers & $\begin{array}{l}8.0 \\
(n=1)\end{array}$ & $\begin{array}{l}2.5 \\
(\mathrm{n}=1)\end{array}$ & $\begin{array}{l}16 \% \\
(\mathrm{n}=1)\end{array}$ \\
\hline Chronic active hepatitis with HBsAg & $\begin{array}{c}10 \pm 6.3 \\
(\mathrm{n}=6)\end{array}$ & $\begin{array}{l}3.5 \pm 2.2 \\
(\mathrm{n}=4)\end{array}$ & $\begin{array}{l}25 \pm 20 \% \\
(\mathrm{n}=4)\end{array}$ \\
\hline Chronic active hepatitis without HBsAg & $\begin{array}{c}8.5 \pm 7.5 \\
(\mathrm{n}=4)\end{array}$ & $\begin{array}{l}3.0 \pm 1.7 \\
(\mathrm{n}=2)\end{array}$ & $\begin{array}{l}12 \pm 6 \% \\
(\mathrm{n}=2)\end{array}$ \\
\hline Chronic persistent hepatitis & $\begin{array}{c}7.1 \pm 4.2 \\
(\mathrm{n}=8)\end{array}$ & $\begin{array}{l}2.8 \pm 1.0 \\
(\mathrm{n}=6)\end{array}$ & $\begin{array}{l}36 \pm 8 \% \\
(\mathrm{n}=8)\end{array}$ \\
\hline
\end{tabular}


On the other hand, blastogenesis by PHA is significantly lower in chronic active hepatitis $(49 \pm 9 \%)$ when compared with normal controls $(61 \pm 8 \%)$ and chronic persistent hepatitis $(53+13 \%)$.

However, no relationship was recognized between HBsAg positive and negative hepatitis patients.

\section{(2) Cyclic AMP contents}

Lymphocyte cyclic AMP contents in chronic active hepatitis with HBsAg were comparatively higher $\left(10.0 \pm 6.3 \mathrm{p}\right.$ mole $/ 1 \times 10^{7}$ of lymphocytes) than normal controls $(6.0 \pm 3.9)$, but these values were not significant statistically.

The contents of lymphocyte cyclic AMP in chronic active hepatitis (CAH) with HBsAg, $\mathrm{CAH}$ without HBsAg and in chronic persistent hepatitis were $10 \pm 6.3,8.5 \pm 7.5,7.1 \pm 4.2$ respectively, and were a little higher when compared with normal controls $(6 \pm 3.7)$ but these values could not be thought to be significant statistically.

(3) Increase-rate of cyclic AMP

Lymphocyte cyclic AMP contents reach maximum at 15 to 20 min after adding PHA to the lymphocyte culture media and the increase-rate by mitogen was higher in normal controls, and progressively lower in HBsAg negative hepatitis patients, asymptomatic carriers of HBsAg and HBsAg positive hepatitis patients in this order (Fig. 1).

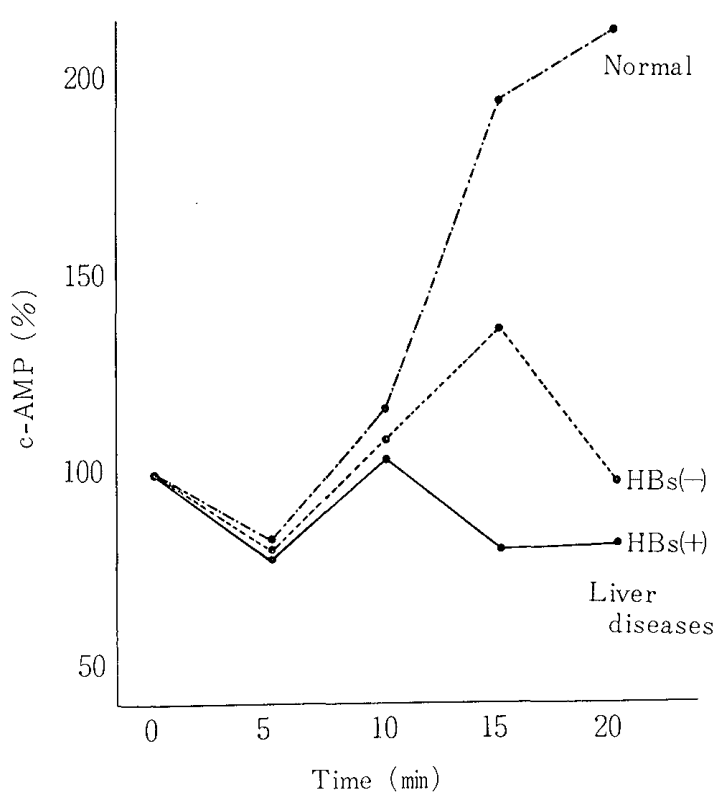

Fig. 1. Variation of lymphocyte cyclic AMP levels (control-rates) after PHA stimulation in hepatitis patients.

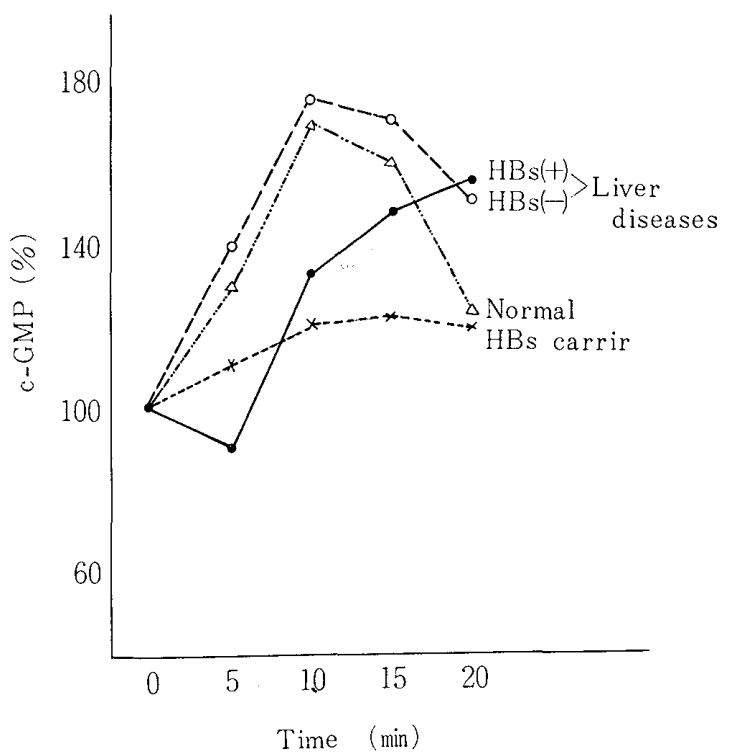

Fig. 2. Variation of lymphocyte cyclic GMP levels (control-rates) after PHA stimulation in hepatitis patients. 
On the contrary, the lymphocyte cyclic AMP contents were lower in normal controls, and progressively higher in asymptomatic carriers of $\mathrm{HBsAg}$, HBsAg negative hepatitis patients, and HBsAg positive hepatitis patients in this order.

\section{(4) Cyclic GMP contents}

Lymphocyte cyclic GMP contents were higher in chronic active hepatitis with HBsAg (3. $5 \pm 2.2 \mathrm{p} \mathrm{mole} / 1 \times 10^{7}$ of lymphocytes), and were less higher in chronic active hepatitis without HBsAg $(3.0 \pm 1.7)$, chronic persistent hepatitis $(2.8 \pm 1.0)$, asymptomatic carrier

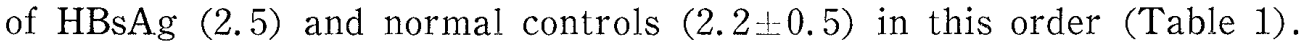

However, these values were not considered to be significant statistically.

(5) Increase-rate of cyclic GMP

Intralymphocytic cyclic GMP contents were increased after adding PHA to the lymphocyte culture media, and reached maximum at 10 to 15 min after the treatment with mitogen, and then the contents were gradually decreased (Fig. 2).

The increase-rate of cyclic GMP $(12 \pm 6 \%)$ were significantly lower in chronic active hepatitis without HBsAg, and tended to be depressed in asymptomatic carriers of $\mathrm{HBsAg}$ $(16 \%)$, chronic active hepatitis with HBsAg $(25 \pm 20 \%)$ and chronic persistent hepatitis $(36 \pm 8 \%)$ in this order.

2. Basic experiment

(1) Correlation between lymphocyte cyclic AMP contents and $\alpha_{1}$-acid glycoprotein ( $\left.\alpha_{1}-\mathrm{AG}\right)$ and $\alpha_{2}$-macroglobulin $\left(\alpha_{2}-\mathrm{M}\right)$ concentrations in culture media

When authentic samples of $\alpha_{1}$-acid glycoprotein $\left(\alpha_{1}-\mathrm{AG}\right)$ was added to the lymphocyte

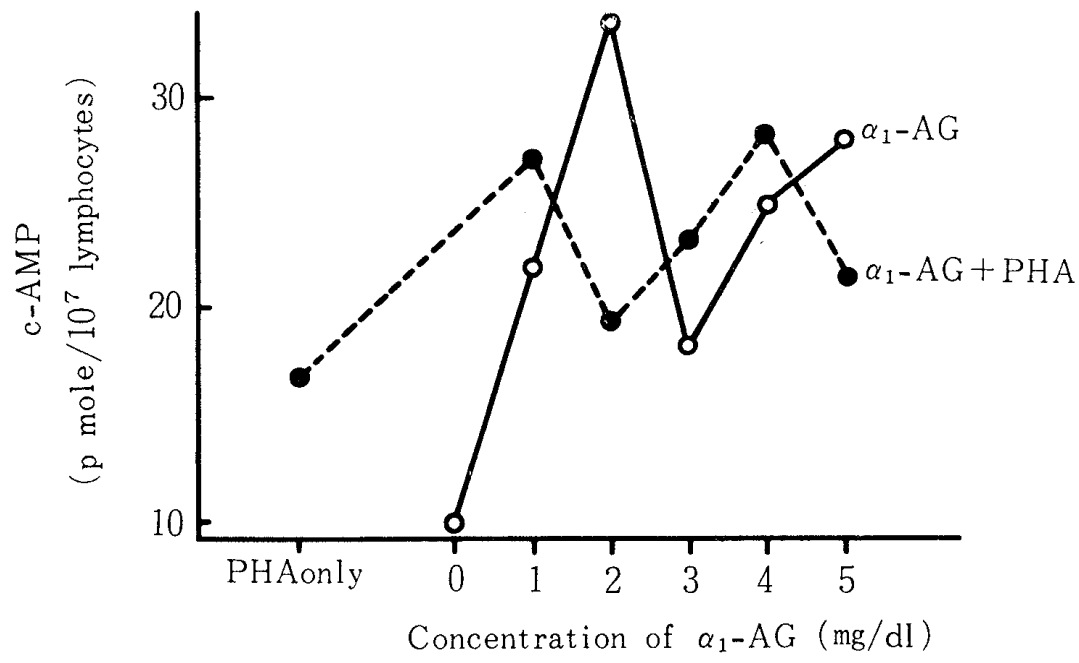

Fig. 3. Variation of intralymphocytic cyclic AMP contents by addition of $\alpha_{1}$-acid glycoprotein and PHA to lymphocyte culture media. 
culture media, the cyclic AMP contents fluctuated and increased irregularly (Fig. 3).

A similar variation curve to that in $\alpha_{1}$-AG could be seen in $\alpha_{1}$-AG with PHA as shown in Fig. 3.

So, we concluded that cyclic AMP contents showed an increase paralleled with $\alpha_{1}$-AG in the culture media in a lower concentration of $\alpha_{1}$-AG up to $2 \mathrm{mg} / \mathrm{dl}$, however, we could not come to any conclusions concerning the results from adding PHA to the culture media with $\alpha_{1}$-AG.

On the other hand, the cyclic AMP contents in lymphocytes were increased by adding authentic samples of $\alpha_{2}$-macroglobulin $\left(\alpha_{2}-\mathrm{M}\right)$ to the lymphocyte culture media, and were paralleled with $\alpha_{2}-\mathrm{M}$ concentration in the culture media up to $100 \mathrm{mg} / \mathrm{dl}$ as shown in Fig. 4 .

(2) Correlation of lymphocyte cyclic AMP contents and suppressor $\mathrm{T}$ cell function with $\alpha_{1}-\mathrm{AG}$ and $\alpha_{2}-\mathrm{M}$ concentrations in culture media

The suppressor $\mathrm{T}$ cell function was estimated by the suppression rate of plaque forming cells (PFC) for sheep erythrocytes after adding lymphocytes which were stimulated by concanavalin-A (Con-A) and were treated with mitomycin-C (MMC) and then were cultured in another system of lymphocyte culture media in which the lymphocytes were stimulated by porkweed mitogen (PWM).

Suppression rates $(\mathrm{PFC}, \%)$ were increased by adding pure $\alpha_{1}$-AG to the lymphocyte cul-
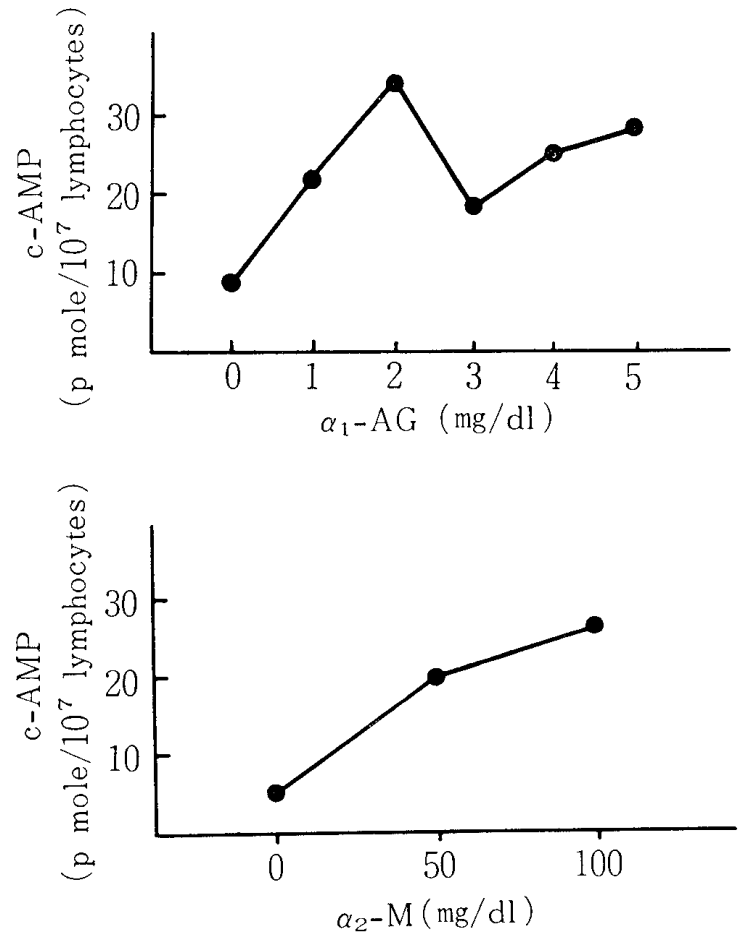

Fig. 4. Variation of intralymphocytic cyclic AMP contents by addition of $\alpha_{1}$-acid glycoprotein and $\alpha_{2}$ macroglobulin to lymphocyte culture media. 


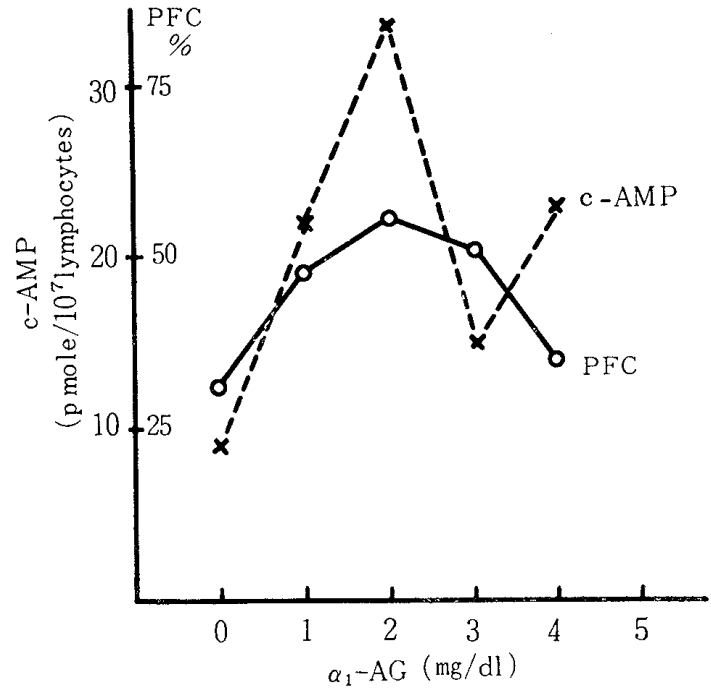

Fig. 5. Variation of intralymphocytic cyclic AMP contents and suppressor $\mathrm{T}$ cell functions (suppression rates, $\mathrm{PFC}$ $\%$ ) by addition of $\alpha_{1}$-acid glycoprotein to lymphocyte culture media.

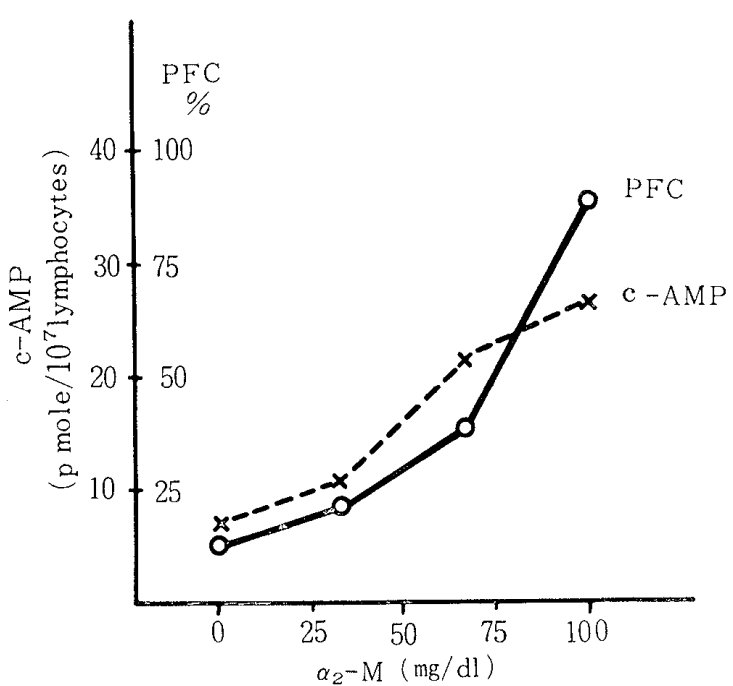

Fig. 6. Variation of intralymphocytic cyclic AMP contents and suppressor $\mathrm{T}$ cell functions (suppression rates, $\mathrm{PFC}$ $\%$ by addition of $\alpha_{2}$-macroglobulin to lymphocyte culture media.

ture media in a lower concentration of $\alpha_{1}$-AG up to $2 \mathrm{mg} / \mathrm{dl}$ paralleled with lymphocyte cyclic AMP contents, and then were gradually decreased up to $4 \mathrm{mg} / \mathrm{dl}$ in a concentration of $\alpha_{1}$-AG in the culture media as shown in Fig. 5.

On the other hand, the suppression rates ( $\mathrm{PFC}, \%$ ) were increased by adding pure $\alpha_{2}$ $\mathrm{M}$ to the lymphocyte culture media and were paralleled with lymphocyte cyclic AMP contents up to $\alpha_{2}$-M concentration of $100 \mathrm{mg} / \mathrm{dl}$ in the culture media as shown in Fig. 6 .

\section{Discussion}

In 1968 Lichtenstein and Margolis presented in "Science" the first evidence implicating cyclic AMP in the control of the leucocyte function. Subsequently, cyclic AMP, acting as a second messenger for vasoactive hormones and as mediators of inflammation, has been shown to modulate a wide variety of immune processes in vitro and in experimental models of immediated and delayed hypersensitivity and the humoral antibody response.

In the in vitro system, cyclic AMP inhibits an immunologic or inflammatory action of leucocytes, and the production of cyclic AMP is stimulated by $\beta$-adrenergic catecholamines, histamin and the E-series prostaglandins.

Hirschhorn et al. (1970) and Henney et al. (1972) observed the effects of cyclic AMP, dibutyryl cyclic AMP and theophylline on lymphocyte stimulation by PHA and on the specific cytolytic activity of lymphocytes.

Also, Smith et al. (1971a, b) and Mendelsohn et al. (1973) studied cyclic AMP concentrations in human peripheral blood lymphocytes after stimulation by PHA, isoproterenol, 
prostaglandins and aminophylline, and then illustrated these compounds elevated lymphocyte cyclic AMP levels and inhibited incorporation of H-labeled thymidine, uridine and leucine into the DNA, RNA and protein of PHA-stimulated lymphocytes.

In their study, aminophylline inhibition was maximal only when the inhibitor was added within one hour after exposure of cells to PHA, suggesting that a relatively early step in the lymphocyte transformation process may be affected.

In our study, lymphocyte cyclic AMP contents after PHA stimulation were enhanced in chronic active hepatitis $(\mathrm{CAH})$ when compared with chronic persistent hepatitis $(\mathrm{CPH})$ and normal controls, suggesting that cellular immunity in $\mathrm{CAH}$ is lower when compared with $\mathrm{CPH}$ or a healthy state.

On the other hand, Hadden et al. (1972) first reported that cyclic GMP acts as an inhibitory agent of the cyclic AMP analog on induction of the immune response.

They illustrated that optimal mitogenic concentrations of PHA and Con-A produced 10 to 50 fold increases in the concentration of 1ymphocyte cyclic GMP within the first 20 min of exposure to the mitogens.

Weinstein et al. (1974) observed that cyclic AMP inhibited the growth of lymphocytes in culture, as well as the lectin-induced transformation of lymphocytes, and that exogenous cyclic GMP and two of its chemical derivatives could stimulate resting mouse spleen lymphocytes to synthesize RNA and DNA, with a time course similar to that caused by Con-A.

Therefore they supposed that cyclic AMP and cyclic GMP act in opposite directions in biological systems, so that the ratio of the two nucleotides within lymphocytes regulates many cell functions.

Bourne et al. (1974) suggest that cyclic GMP and cyclic AMP may act in a 'push-pull' fashion to regulate functions of lymphocytes, neutrophils and even most other cells, that is, wherever cyclic AMP appears to inhibit a reaction, cyclic GMP may enhance it. Similarly, wherever sympathetic neurohormones (catecholamines) appear to act through cyclic AMP, the parasympathetic neurotransmitter, acetylcholine (or its congeners), may

$\alpha_{1}$-Acid glyounroin

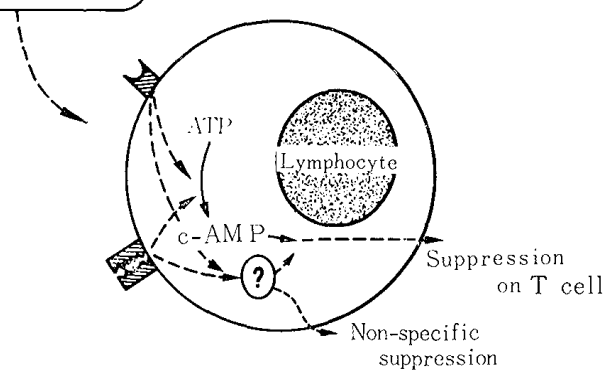

Fig. 7. Hypothetical concept of the role of cyclic AMP on cellular immunity related with $\alpha_{1}$-acid glycoprotein and $\alpha_{2}$-macroglobulin (I).

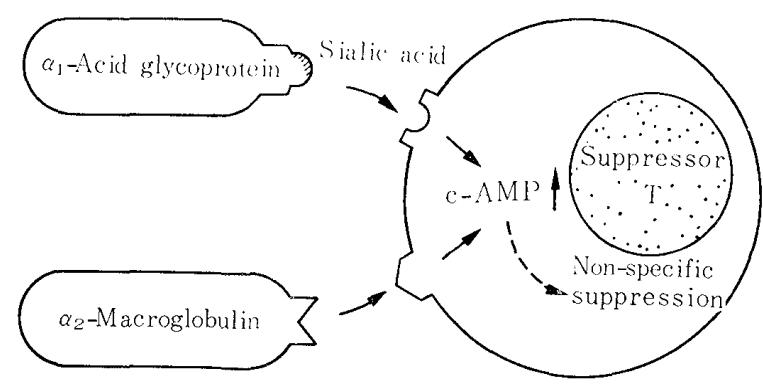

Fig. 8. Hypothetical concept of the role of cyclic AMP on cellular immunity related with $\alpha_{1}$-acid glycoprotein and $\alpha_{2}$-macroglobulin (II). 
act through cyclic GMP.

In our data, lymphocyte cyclic GMP contents after PHA stimulation tended to enhance in $\mathrm{CAH}$ when compared with $\mathrm{CPH}$ and normal controls, however, these values were not thought to be significant statistically.

On the contrary, the increase-rate of lymphocyte cyclic GMP at 15 min after PHA stimulation were significantly decreased in CAH, especially in a HBsAg negative patient, as compared with $\mathrm{CPH}$ or healthy person.

Therefore, we suppose that depressed increase-rates of lymphocyte cyclic GMP after mitogen stimulation express the suppressed cellular immunity in the hepatitis patient, whereas the cyclic GMP contents in T-lymphocytes are not significant markers related to immunity.

In the in vitro experiments, we have recognized that the addition of exogenous $\alpha_{1}$-acid glycoprotein and $\epsilon_{2}$-macroglobulin to the lymphocyte culture media enhanced the cyclic AMP contents in lymphocyte paralleled with the concentrations of $\alpha_{1}$-AG and $\alpha_{2}-\mathrm{M}$ in the culture media.

On the other hand, plaque forming cells (PFC, \%) were similarly increased to lymphocyte cyclic AMP contents paralleled with the concentrations of $\alpha_{1}$-AG and $\alpha_{2}-\mathrm{M}$ in the culture media.

These findings suggest that $\alpha_{1}-\mathrm{AG}$ and $\alpha_{2}-\mathrm{M}$ may act as serum inhibitors against cellular immunity mediated with enhanced contents of lymphocyte cyclic AMP (and presumably, with the depressed increase-rate of lymphocyte cyclic GMP).

These hypotheses might be true since the suppressor $\mathrm{T}$ cell function ( $\mathrm{PFC}, \%$ ) was increased and was paralleled with the cyclic AMP contents in lymphocytes and the $\sigma_{1}-\mathrm{AG}$ and $\alpha_{2}-\mathrm{M}$ concentrations were increased in lymphocyte culture media (Figs. 7,8 ).

\section{Conclusion}

Lymphocye cyclic AMP contents after PAH stimulation were enhanced in chronic active hepatitis $(\mathrm{CAH})$ when compared with chronic persistent hepatitis $(\mathrm{CPH})$ and normal controls (NC).

On the other hand, the increase-rate of lymphocyte cyclic GMP after the mitogen stimulation were depressed in $\mathrm{CAH}$ as compared with $\mathrm{CPH}$ and $\mathrm{NC}$.

No relationship could be observed between these results and HBsAg.

These findings may be compatible with suppressed cell mediated immunity in chronic viral hepatitis especially in chronic active hepatitis, and suggest that lymphocyte nucleotides may regulate the immune mechanism in the course of viral hepatitis.

\section{Acknowledgement}

We wish to thank Miss Chiaki Sakurai for her excellent assistance in the writing of this paper. 


\section{References}

Bourne, H. R., Lichtenstein, L. M., Melmon, K. L. et al. (1974): Modulation of inflammation and immunity by cyclic AMP. Science, 184: 19-28.

Gilman, A. G. (1970): A protein binding assay for adenosine $3^{\prime}, 5^{\prime}$-cyclic monophosphate. Proc. Nat. Acad. Sci. USA, 67: 305-312.

Hadden, J. W., Hadden, E. M., Haddox, M. K. et al. (1972): Guanosine $3^{\prime}, 5^{\prime}$-cyclic monophosphate: A possible intracellular mediator of mitogenic influences in lymphocytes. Proc. Nat. Acad. Sci. USA, 69: 3024-3027.

Henney, C. S., Bourne, H. R. \& Lichtenstein, L. M. (1972): The role of cyclic $3^{\prime}, 5^{\prime}$ adenosine monophosphate in the specific cytolytic activity of lymphocytes. J. Immunol., 108: 1526-1534.

Hirschhorn, R., Grossman, J., Weissmann, G. et al. (1970): Effect of cyclic 3', 5'-adenosine monophosphate and theophylline on lymphocyte transformation. Proc. Soc. Exp. Biol. Med., 133: 1361-1365.

Lichtenstein, L. M. \& Margolis, S. (1968): Histamine release in vitro: Inhibition by catecholamines and methylxanthines. Science, 161: 902-903.

Mendelsohn, J., Multer, M. M. \& Boone, R. F. (1973): Enhanced effects of prostaglandin $\mathrm{E}_{2}$ and dibutyryl cyclic AMP upon human lymphocytes in the presence of cortisol. J. Clin. Invest., 52: 2129-2137.

Murad, F. \& Gilman, A. G. (1971): Adenosine $3^{\prime}, 5^{\prime}$-monophosphate and guanosine $3^{\prime}, 5^{\prime}$-monophosphate: A simultaneous protein binding assay. Biochem. Biophys. Acta, 252: 397-400.

Murad, F., Manganiiello, V. \& Vaughan, M. (1971): A simple, sensitive protein-binding assay for guanosine 3', 5'-monophosphate. Proc. Nat. Acad. Sci. USA, 68: 736-739.

Smith, J. W., Steiner, A. L., Newberry, W. M., Jr. et al. (1971a): Cyclic adenosine 3', 5'-monophosphate in human lymphocytes. Alterations after phytohemagglutinin stimulation. J. Clin. Invest., 50: 432-441.

Smith, J. W., Steiner, A. L. \& Parker, C. W. (1971b): Human lymphocyte metabolism: Effects of cyclic and noncyclic nucleotides on stimulation by phytohemagglutinin. J. Clin. Invest., 50: $442-448$.

Steiner, A. L., Kipnis, D. M., Utiger, R. et al. (1969): Radioimmunoassay for the measurement of adenosine $3^{\prime}, 5^{\prime}$-cyclic phosphate. Proc. Nat. Acad. Sci. USA, 64: 367-373.

Taoka, Y. (1980): The role of suppressor T-lymphocyte during the course of human and murine viral hepatitis associated with antibody dependent cell-mediated cytotoxicity (ADCC). J. UOEH, 2: 481-292.

Taoka, Y. \& Endo, T. (1978): Chronicity of viral hepatitis in nude mice inoculated with mouse hepatitis virus (MHV)-type II. VI World Congr. of Gastroenterol., Madrid. June 5-9, 1978, Abstracts of Papers, p. 64.

Taoka, Y. \& Endo, T. (1979a): Chronicity of viral hepatitis and cell-mediated immunity (1)-Tlymphocytes transfer to liver tissue in MHV-II hepatitis mice-. J. UOEH, 1: 459-463.

Taoka, Y. \& Endo, T. (1979b): Chronicity of viral hepatitis and cell-mediated immunity (2)-Especially on non-specific serum inhibitors for cellular immunity--. J. UOEH, 1: 465-470.

Taoka, Y. \& Endo, T. (1979c): Chronicity of viral hepatitis and its association with cell-immunity, especially on the relationship between the serum inhibitor for lymphocyte transformation and intracellular contents of cyclic nucleotides. V Internat. Congr. Liver Diseases "Virus and the Liver," Basel. October 5-7, 1979, Poster Session Abstracts, pp. 162-163.

Taoka, Y. \& Endo, T. (1980a): Chronicity of viral hepatitis and cell-mediated immunity (3)-Effect of antithymocyte and antiplasmocyte sera infusion on experimental hepatitis mice--. J. UOEH, 2: $75-83$.

Taoka, Y. \& Endo, T. (1980b): Chronicity of viral hepatitis in nude mice inoculated with mouse 
hepatitis virus (MHV)-type II. J. UOEH, 2: 215-233.

Taoka, Y. \& Endo, T. (1980c): Relationship between suppressor T-lymphocyte function and lymphocyte transformation by PHA in human viral hepatitis. Hepato-Gastroent. (Supplement): Abstracts XI Internat. Congr. Gastroenterol. - A. S. N. E. M. G. E. -Hamburg. June 8-13, 1980. Georg Thieme Verlag Stuttgart, New York. p. 303.

Weinstein, Y., Chambers, D. A. \& Bourne, H. R. et al. (1974): Cyclic GMP stimulates lymphocyte nucleic acid synthesis. Nature, 251: 352-353.

ヒト・ウイルス肝炎におけるリンパ球内サイクリック・ヌクレオチドの

動態と宿主免疫機構との関連

由岡 賢雄 ${ }^{1}$ - 遠藤 高由 ${ }^{2}$

1産業医科大学第三内科学教室２沼津市西沢田クリニック

要 旨： 1968 年 Lichtenstein らがリンパ球内サイクリック AMP が生体内の免疫機構の調整に 関与している可能性を示唆して以来，ての問題については今日までに多くの研究があり， サイクリック AMP レベルの増加は T 紐胞機能に対して抑制的に，PHA 刺激後のサイ クリック GMP レベルの増加は T 細胞機能に対して促進的に働くことが明らかとなり， サイクリック AMP とサイクリック GMP とは生体の免将機構に対し相互に拮抗的ないし 相補的に作用することが明らかとなった。しかし，ヒト・ウイルス肝炎についてての点を 検討した報告は末だなく，乙の点を中心に追究するとともに，合わせて血清免疫別制因子 との関連についての基礎的検討を行った。著者の成績によれば $\mathrm{T}$-細胞機能の低下がみら れる慢性活動性肝炎では慢性非活動性肝炎や健常例に比して， T-リンパ球内サイクリッ

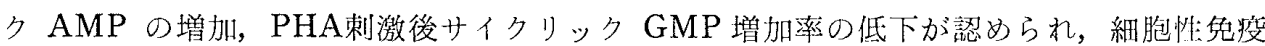
の抑制が示唆された。この場合 $\mathrm{HBsAg}$ の有無との閒には関連はみられなかった。・方， in vitro の実験では T-リンパ球内サイクリック AMP 含量は PFC \%よりみた抑制性 $\mathrm{T}$ 細胞（サプレッサーT，Ts）機能とよく並行しており，またりンパ球㙖養液中に添加 した細胞性免度抑制因子と考えられている $\alpha_{1}$ 一酸性糖夕ンパク $\left(\alpha_{1}-\mathrm{AG}\right)$ や $\alpha_{2}$-マクログロ ブリン $\left(\alpha_{2}-\mathrm{M}\right)$ の濃度ともよく並行しており，乙れら培養液中の血清抑制因子がリンパ 球内ヌクレオチドの含量に大きな影薌を与えているてとが判明した，以上，ヒト・ウイル 又肝炎においても Tーリンパ球内サイクリック・ヌクレオチドはその増減を介して $\mathrm{T}$ 細胞 機能を調節し生体の免将機構に関与していることが強く示唆された。

J. UOEH（産業医大誌)， 3(4)：363-373 (1981) 